\title{
Effects of employing In-service EFL Teachers Strategy-based Instruction on their Performance of Teaching Listening Comprehension in Amman-Jordan
}

\author{
NAIMA AHMAD AL-HUSBAN \\ Arab Open University, Jordan \\ n_husban@aou.edu.jo
}

\begin{abstract}
This study investigated the effect of a proposed training program based on strategy-based instruction (SBI) on EFL female teachers' performance in teaching listening comprehension. The participants of the study were 36 EFL female teachers who were purposefully chosen by EFL supervisors from schools in Amman. The participants were randomly divided into two groups: 18 EFL teachers in the experimental group who were trained according to the proposed training program and 18 teachers in the control group who were received a conventional training program. A teaching listening comprehension scale and an observation checklist were used as research tools. Analysis of covariance (ANCOVA) was employed to identify any statistically significant differences between the two groups on teachers' performance in teaching listening comprehension. The findings revealed that the teaching performance in listening comprehension of female EFL teachers in the experimental group outperformed the control group, and employed most of the SBI when the participants were observed. Based on the results of the study, the researcher recommends that future research be investigated on the effect of research-based strategies on teacher effectiveness in teaching other language skills.
\end{abstract}

Keywords: in-service EFL teachers; Strategy Based Instruction; listening comprehension; EFL teacher' performance; research-based strategies

\section{INTRODUCTION}

Learning English as a Foreign Language (EFL) has been one of main concerns of most speakers of English as a foreign language. This is due to the necessity of mastering the four language skills: listening, speaking, reading, and writing. Listening skills are the main component of language learning. However, these skills have not been given attention in the classroom due to reliance on traditional methods (Amaluddin et al., 2018). It is important to investigate the effectiveness of employing Strategy Based Instruction (SBI) in the primary classroom as it is proven by research (Oxford, 2003), and this is the goal of the current study.

\section{LISTENING SKILLS AND LISTENING COMPREHENSION}

Listening skills are significant in foreign language classrooms because their main function is for the learner to receive input, which is the key to successfully learning the language (Gilakjani \& Sabouri, 2016). According to Hamouda (2013), Krashen and his colleagues (1989) explained that language acquisition takes place when children receive enough comprehensible input. Similarly, Hasan (2000) stated that listening comprehension gives suitable contexts for acquiring and mastering the other language skills. Furthermore, listening is important in the communication process; that is, students need to receive information and understand it to interact and communicate with others (Hamouda, 2013). Therefore, it is necessary to define listening comprehension.

According to Sary (2017), Howat and Dakin (1974) stated that listening is the ability of identifying and understanding what is said. This entails learners receive pronunciation, words, and grammar to understanding their meaning. Sary (2017) highlighted that listening is the main stage of learning as any person could speak, communicate, and interact with others without listening at the beginning, and in natural contexts, people spend half of their time listening (Barker et al., 1980). 
However, from that time until now this skill received the least attention particularly in teaching and learning context. Call (1985) and Osada (2004) clarified that the negligence of teaching this skill stemmed from the belief that listening is a passive skill, and merely exposing students to the language is enough to develop the listening skills.

Another reason for this negligence could be the difficulty of teaching this skill, and the focus of teachers on assessing students rather than teaching them how to listen effectively, analyze, evaluate, and making judgments (Alam, 2009). This leads to the necessity of teaching English language in an untraditional way by giving students opportunities to participate and engage in the social contexts. This requires that an active listening process should take place to ensure learners acquire language (Sari, 2017). Underwood (1989) stated a similar idea; that is, listening is different from hearing. Listening is the process of receiving sounds, decoding them actively, and understanding them in context, which obviously requires the listeners to be fully attentive to what is said. To make sure this happens, good teachers must be well equipped with knowledge and skills to teach listening comprehension to the degree that helps students acquire the skill rather than just practice it (Field,1998).

It is worth noting that this idea is highlighted by Philip et al. (2019); that is, teachers are the most substantial component of the teaching learning process, because their knowledge and pedagogy constitute what teachers employ in the classroom. Therefore, it is essential to nurture teachers' pedagogical knowledge so as to employ effective strategies while teaching specifically teaching English as a foreign or second language.

Teaching listening is not just playing the tape and testing students (Sari, 2017; Gilakjani \& Sabouri, 2016; Krebt \& Al-Rifai, 2013). According to Chien \& Wei (1998), students need teachers help them to activate all their previous schemata, background knowledge and the context of the situation

\section{TEACHING LISTENING COMPREHENSION IN JORDAN}

The status of teaching listening comprehension in Jordan is no longer different from the international one, that is, listening comprehension is the most neglected skill among other ones. According to Obeidat and Abu-Melhim (2008) and Abu-Mwais and Smadi (2017), in Jordan students finish their study after 12 years of studying English language without being able to comprehend spoken text by a native speaker, this is due to the way of learning Listening comprehension, that is, teachers read the scripts and translate them, and teachers do not teach students' listening skills. This leads to reducing the interest and the motivation of students towards this skill.

Furthermore, Alrawashdeh and Al-Zayed (2017) stated the proficiency of EFL teachers is the main reason that EFL teachers do not present the skill effectively; that is, they read the scripts, then ask students some factual questions about the scripts. This reveals there is an urgent need to focus on training teachers on how to employ research -based instructional strategies of listening comprehension.

In 2019, Phenix Center for Economics and Informatics indicated that the educational system in Jordan is facing several challenges. This study revealed that the quality of the educational system in Jordan is problematic in spite of the great efforts exerted by the Ministry of Education (MoE) and its partners to provide all the necessary educational services. The study revealed that Jordan has dropped in international ranking tests, like the British Prosperity Index, which revealed education in Jordan dropped from $45^{\text {th }}$ rank in 2012 to the $64^{\text {th }}$ rank in 2013, and to $75^{\text {th }}$ in 2019, and this revealed the very low level that education achieved over years according to the Education First English Proficiency Index. This rang the bell to analyze the challenges leading to the decline in the quality of education in Jordan. It found that one of 
the main challenges is teachers' lack of effective teaching strategies and an appropriate developing framework.

This shocking fact demonstrates the importance of teachers who can make essential transformations in the learner's achievement if they have been well prepared for teaching and later developed professionally. Therefore, training EFL teachers should be given the highest priority by the MoE to equip these teachers with the pedagogical knowledge and skills and to improve their performance in teaching the four language skills: listening, speaking, reading, and writing. Ultimately, this enhances the students' learning outcomes and meets the changes of modern times.

In-service training is considered the main source of professional development for teachers of all subject matters in Jordan, particularly the English language. At the same time, according to Al- Saleem (2011), these programs required to be reviewed to leverage the achievement of the Jordanian learners in the English language; the revision should follow an efficient strategy that not only develops teachers but also fosters their performance in teaching EFL.

Within this context, several studies were conducted to investigate how EFL teachers perceive the in-service training programs prepared and implemented by the MoE in Jordan. For instance, Bani Abdo and Breen (2010) examined the strategies EFL teachers employed while teaching EFL students. They found that many EFL teachers were not adequately equipped or prepared to acquire the linguistic teaching methods. This result, besides teachers' inability to employ effective EFL teaching methods, explains why so many Jordanian learners struggle in learning English language.

According to Al-Husban and Al-Khawaldeh (2016), in order to provide quality education, the teachers should be exposed to quality pre- service preparation and effective continuous professional development programs. According to Darling-Hammond (2009) and Khan (2011), the best trained and most professional teachers were those who participated in training programs focusing on how to implement SBI and their techniques in the classroom and, consequently, develop their pedagogical performance.

As such, Khan (2011) agreed with Marzano (2011) and Oxford (2003) on the need for adopting research-based approaches to teachers' training and professional development. Marzano (2011) focused on providing teachers with a repertoire of effective strategies and methods whose effectiveness on learners' achievement has been proven. Accordingly, it would be the responsibility of the teacher to select suitable strategies in different teaching situations, as there is no formula for effective teaching. In other words, research cannot identify instructional strategies that work well with every student in every classroom, but it can guide teachers to implement the most effective ones while teaching instead of experimenting with new, unproven strategies. (Al-Husban \& Al-khawaldeh, 2016).

\section{STRATEGY BASED INSTRUCTION (SBI): OXFORD 'S MODEL}

Strategy-based instruction is remarkably demonstrated by Oxford's model (1990) of English language instruction. Oxford (1990) was among the first to assure that SBI should be part and parcel of teaching English as a foreign or second language, as it helps learners to be proficient, confident, and self- aware of how to learn the English language. This model also differentiated between direct and indirect strategies, many researchers like, field (1998), Jones (1998), Dahlberg (2016), and Rahimi (2012) developed their models of SBI, but Oxford (1990) developed a model of language teaching strategies that is more comprehensive than the previous ones. Oxford in her turn explained the direct strategies involved in learning the subject matter using three categories of strategies: memory strategies, cognitive strategies, and compensation strategies. 
Whereas, indirect strategies play a role in learning in an indirect but powerful way, they are in three categories: meta-cognitive strategies, affective strategies, and social strategies. According to Oxford (2003), six major groups of L2 learning strategies were identified in a clearer way:

- Cognitive strategies enable learners to learn the language directly using reasoning, analysis, note taking, summarizing, outlining, and rearrange information to develop powerful schemas.

- Metacognitive strategies include a focus on learners' learning styles preferences, planning tasks, monitoring mistakes, evaluating task success, they are for managing the learning process.

- Memory strategies: help learners link knowledge with previous one, they are important in the initial stage of learning a language for memorizing necessary vocabulary and structures.

- Compensatory strategies: include guessing information in listening, using gestures or pause words helps learners make up for missing knowledge.

- Affective strategies include identifying learners' mood and anxiety level, feelings, and rewarding for good performance.

- Social strategies include asking questions for clarification of a complex point, asking for help in doing tasks, this group of strategies helps learners work with others and understand the target culture and language.

According to the review of literature, this model of English language skills instruction is in line with the international implications of teaching English language skills, and listening comprehension is one of them, that is, teaching according to the students' preferences ensure learning will takes place, as students will involve and build the language in his/her mind according to the principles of the constructivism theory of learning (Hein, 1991).

Furthermore, this model, that includes categories of strategies not only one strategy, complements with the international assumption that no single instructional strategy fits all students, teachers would be better when employing a range of strategies that meet the various needs and preferences of student (Fathi \& Hamidizadeh, 2019; Dahlberg, 2016; Rahimi, 2012; Oxford, 2003 \& Field, 1998).

Thus, in the present study, the researcher prepared a training program using Oxford's strategies of listening comprehension due to the need of teachers to be trained on how to employ them in the classroom especially in listening comprehension instruction.

Listening comprehension plays a major role in everyday communication and comprehension cannot be developed as easily as the mother language. It needs more effort from learners to acquire linguistic clues, and support from teachers by employing various instructional strategies to ensure English language learning (Zhang, 2012) \& Chien \& Wei (1998).

Additionally, most research is conducted to measure the effect of listening comprehension strategies on student achievement (Gilakjani \& Sabouri,2016; Bell, 2018; Sary, 2017; Zeng \& Goh, 2018 and Krebt \& Al-Rifai, 2013). However, little research has been conducted to leverage EFL teachers' performance in teaching listening comprehension (Moradi, 2013). It is notable that Oxfords' model of strategy instruction fits the principles of the constructivist theory, which focuses on active learning, catering to individual differences. Its strategies are tools for active and self-directed involvement, and learners will be responsible for their own learning. 


\section{PURPOSE AND RATIONALE}

This study aims to investigate the effects of training EFL teachers on using SBI on their performance while teaching listening comprehension.

This study provided beneficial insights and significant implications that foster the instructional performance of EFL teachers in teaching listening comprehension.

Additionally, the proposed training program met the needs of EFL teachers due to its anticipated provision of non-traditional and practical knowledge about how to teach effectively and improve the implementation level of instructional strategies of listening comprehension, the neglected skill, as described by the body of research. Further, this study drew the attention of researchers to the necessity of taking proven strategies into consideration while conducting this type of study. This idea is reinforced by Lear (2019), that is, professional development programs play a role in enhancing quality-teaching practices of teachers.

Practically, this study was built on the Oxford comprehensive strategy-based instruction, which has been suggested and implemented in many schools, districts, and states all over the world especially in countries that consider English as a second or foreign language. Furthermore, this study was intended to narrow the gap between research and teaching practices by implementing the recommendations and the conclusions of many related national studies such as Al-Saleem (2012) who proposed that EFL teachers should be provided with practical rather than theoretical training.

Finally, this study provided educational supervisors and school principals with tools to help them assess the levels of EFL teachers' performance and how they implement instructional strategies in their classrooms to produce large gains in student learning. Moreover, this study provides EFL curriculum adapters with insights and understanding regarding the elements and the strategies that influence listening comprehension and make it easier for students to grasp listening tasks.

\section{LITERATURE REVIEW}

According to Zhang (2012) and Amaluddin et al. (2018), a strategy -based instruction is important for teachers to use as they help learners develop listening comprehension, and research revealed that good learners used various metacognitive, cognitive, and social strategies, and the less able learners became better when they were taught these strategies (Osada, 2004; \& field, 1998). Likewise, Sulaiman et al., (2020) clarified that cognitive strategies, as a part of the strategy-based instruction, are quite significant to learners because the more learners practice them, the more they could recognize texts, make inferences, and eventually understand it thoroughly.

However, some researchers criticized this model, as learners could not recognize a system of new thoughts that were totally different from their current ones since they had already acquired the compensation strategies. This reveals the importance of training teachers to resolve this contradiction and identifying which strategies learners need more, which they are familiar which, and which they do not need at all.

Furthermore, Giraldo (2014) examined the impact of a professional development program on the instructional performance of in-service English teachers in Colombia and the change in their teaching practice. The sample of the study was six novice in-service teachers. A questionnaire and classroom observations were used to collect data about the development of English language teachers' performance.

Results showed that the professional development program had a direct effect on optimizing English language teacher's performance and they demonstrated awareness of the effective strategies they were exposed to in the program. Results also showed that teacher's 
performance before the training program was traditional, focusing on structure and translation. However, after finishing the program, they demonstrated a communicative way of teaching, engaging students in the learning process, identifying the learning objectives and providing feedback, and increasing the motivation of students.

Ramli, Saukah, and Prayogo (2019) conducted a research showing the importance of word recognition from speech, syntactic knowledge, meta-cognitive awareness, and selfefficacy to ESL students. Findings revealed that ESL teachers could provide word recognition from speech, syntactic knowledge based on students' needs, and can activate students' metacognition.

This revealed the prominent role of teachers in enhancing students' listening skills by employing strategy-based instruction like Oxfords where cognitive and metacognitive strategies are part of her direct model. Similarly, Rahimirad and Zare-ee (2015) conducted a study about the effect of metacognitive strategy-based instruction on EFL learners, sixty female undergraduates participated in the study, and they were divided into an experimental group, which received a training program based on strategy-Based instruction and a control group taught traditionally. Findings revealed that the effectiveness of teaching listening comprehension using metacognitive strategies as they increase the awareness of students of the listening skills necessary to comprehend the spoken texts. Results also indicated that EFL teachers should pay much attention to these strategies due to their prime role in fostering listening comprehension.

Additionally, Zhang (2012) conducted a study about the effectiveness of strategy-based instruction towards listening comprehension including many of Oxford's strategies like the cognitive, metacognitive, and social strategies. Results showed that employing these strategies by EFL teachers increased positively the listening comprehension of students, and leverage the communication skills of EFL learners because EFL learners acquire more knowledge of the language while practicing listening comprehension, so their speaking competence will be better (Manzano, 2018).

Zobler (2010) also stated that a strategy-based instruction provides EFL teachers with the tools that help learners to learn the language effectively, the author trained EFL teachers for 8 weeks on strategy-based instructions including most Oxford's strategies in her model. Results revealed that EFL teachers could boost student's listening competence through employing a strategy-based instruction models like Oxfords' and reappraising their role as teachers of listening. Vandergrift (2003) also reached similar results in students' ability of comprehending spoken text after employing strategy-based instruction.

Similarly, Sarafianou and Gavriilidou (2015) conducted a study to investigate the effects of Oxford's model of strategy-based instruction on Greek EFL learners' results showed that the experimental group revealed a significant development in using all the domains of SBI, this unveils the teach-ability of the model and it is necessary to be embedded in EFL classrooms.

Even though most studies focused on students as their target group, a few studies were conducted to develop EFL teachers by equipping them with effective strategies to improve their performance and practices while teaching listening comprehension. For example, Abril Molina and Pardo (2016) investigated the effect of a proposed training program on EFL teachers' listening comprehension practices and the development of the skill in their learners. The study aimed to develop EFL teachers' performance in teaching listening comprehension after identifying their needs and building a training program that aimed to meet these needs. Results revealed that EFL teachers needs to boost their listening comprehension instructional strategies as well as other professional development components. 
The review of the previous related studies indicated that Oxford's model of strategybased instruction has been displayed to be effective with respect to student's achievement and communication. This review also pinpoints that the most essential factor that makes changes in the minds of students is the teacher. However, English as foreign language teachers have not received adequate attention from researchers and trainers. Forty years ago, listening comprehension was deemed an un-teachable skill as it was assumed to be learnt automatically (Ulum, 2015).

In fact, few of the listening research conducted since 1970 emphasized developing EFL or language teacher's ability in teaching listening comprehension using research-based strategies (Ulum, 2015). In this vein, it is significant to focus more on equipping EFL teachers with a range of strategies regarding how to teach the four language skills, especially listening comprehension, the ignored skill.

\section{METHOD}

\section{RESEARCH QUESTION}

This study attempted to answer the following questions:

1- Is there any effect of training EFL female teachers on employing Oxford's model of strategy-based instruction on their teaching performance?

2- Do EFL female teachers employ the model's strategies after participating in the training program?

\section{DESIGN}

The methodology used in this study was quantitative following a quasi-experimental design. This study has an independent variable, which is the proposed training program, and a dependent variable, which is EFL teacher's performance in teaching English language, and the pre and post scales measured it.

To answer the research questions, the researcher used descriptive statistics such as the mean scores and standard deviations. Additionally, inferential statistics "analysis of covariance (ANCOVA)" was used due to the lack of randomization in the sample selection to check the equivalence between the groups as well as the effect of the proposed training program.

\section{PARTICIPANTS}

The population of the study consisted of all EFL female teachers who taught English language at the upper primary stage in Amman in the first semester of the academic year 2018/2019. The total number of those EFL female teachers was 153, though this included teachers who taught some lower basic classes or secondary classes.

The study sample consisted of 36 female EFL teachers, who were chosen purposefully from twenty schools by their EFL supervisors. Their experience was below two years, and their ages were from 26 to 32 years old. Then, (36) female EFL teachers were randomly distributed into two groups: experimental and control, with 18 female EFL teachers in each group.

The experimental group (of 18 EFL teachers) was trained according to the proposed training program. Their teaching performance was assessed using an instructional scale. However, the control group was trained according to the conventional program prepared by the EFL supervisors at the Directorate of Education. Their teaching performance was assessed using a teaching scale. 


\section{INSTRUMENTS}

\section{PROPOSED TRAINING PROGRAM}

A proposed training program was developed according to Oxfords' model of strategy-based instruction of listening comprehension to optimize EFL teacher's performance in teaching listening comprehension. It included the purpose of the training program; the activities which were designed to present and practice Oxfords' model based on the content of units from the student's book of the $9^{\text {th }}$ grade; and directions on how to use the instructional strategies effectively.

In this program, the focus was Oxford's model that teacher effectiveness in teaching listening comprehension helps learners gain greater proficiency, confidence and selfawareness. It also focused on helping teachers to be more learner-centered, supporting high quality instruction, and extending student's learning by manipulating content in textbooks.

Likewise, the program concentrated on hands-on techniques rather than on theoretical approaches. It emerged from the findings of a body of research, which has proven the efficacy of these strategies and their role in prompting student's awareness, autonomy, and selfdirection. The researcher used many activities in Oxford's book language learning strategies: what every teacher should know, for example, the strategy of employing actions in the direct category, Oxford explained that there are two techniques an EFL teacher could use:

- Using physical response, by asking students to act out a new expression they could not explain it linguistically (Oxford, 1990, p.66)

- Using mechanical techniques like flash cards to help students remember what they listened to (Oxford, 1990, p.68).

The content of the proposed training program, its sessions and design, and its suitability were validated by a panel of experts in teaching English as a Foreign Language. They were asked to check the content of the training program. All feedback focused on rewording some concepts to make them familiar to EFL teachers, and adopting certain arrangements for the strategies to represent them more meaningfully. All the points regarding language and classification of the strategies have been taken into consideration.

\section{A SCALE FOR TEACHERS' PERFORMANCE OF LISTENING COMPREHENSION}

The purpose of the scale was to examine the effect of the proposed training program on EFL female teacher's performance. The researcher developed a scale as a pre-test to examine the equivalence between the experimental and the control groups. It was also used as a post-test to identify the effect of the proposed training program on improving EFL teachers' performance in teaching listening comprehension.

The researcher identified the items to reflect all of strategies embedded in Oxford's model. The scale was validated by a jury of specialists. They were asked to examine the items and their alternatives. All of their points focused on rewording some alternatives to be clearer to EFL teachers. All of the points were taken into consideration. To establish the reliability of the vocabulary teaching performance scale, it was applied to a pilot sample from outside the study sample. The sample consisted of 13 EFL teachers. The internal consistency coefficient was computed using Cronbach Alpha formula. It was 0.85, this result was considered appropriate for the purpose of this study. 


\section{A STRUCTURED OBSERVATIONAL RATING SCALE}

A structured observational rating scale was constructed in the light of the training program, and consisted of the strategies that proposed in Oxford's model. It was employed after exposing the sample of the study to the training program to verify the long-term effect of the training program, and the frequencies of teacher's employment of these strategies. To verify its reliability, EFL teachers were observed by the researcher, and a co-rater, then the agreement coefficient was measures, it was 0.89 , and it was appropriate for the purpose of this study.

\section{RESULTS}

The statistical tests were implemented using the Statistical Package for Social Science (SPSS 24).

Question no (1): Is there any effect of training EFL female teachers on Oxfords' model of strategy-based instruction on their teaching performance? To answer this question, a null hypothesis was formulated as follows: There are no statistically significant differences at $\alpha=$ 0.05 in the mean scores of the performance of EFL teachers in teaching listening comprehension scale between the experimental group and the control group of EFL teachers due to the training program based on Oxford's model and the conventional one.

To verify this hypothesis, means and standard deviations of the EFL female teachers' performance in the scale of teaching listening comprehension were calculated, and one-way ANCOVA was used to check the effect of the proposed training program on EFL teacher's performance in teaching listening comprehension. Table 1 below shows the means and standard deviations of the teacher's performance in teaching English language.

TABLE 1. Means and standard deviation for the experimental and control groups on teaching performance scale

\begin{tabular}{ccccccc}
\hline Group & N & $\begin{array}{c}\text { Pre- test of scale } \\
\text { Mean }\end{array}$ & $\begin{array}{c}\text { Std. } \\
\text { Deviation }\end{array}$ & N & Post -test of scale \\
Mean & $\begin{array}{c}\text { Std. } \\
\text { Deviation }\end{array}$ \\
\hline Experimental & 18 & 11.5 & 1.83 & 18 & 20.5 & 1.51 \\
Control & 18 & 9.5 & 1.11 & 18 & 11 & 1.31 \\
Total & 38 & 21 & 2.94 & 38 & 31.5 & 2.82 \\
\hline
\end{tabular}

Table 1 shows that the mean score of the experimental group in the pre- test was 11.5 out of 25, with a standard deviation of 1.83 , and the mean score of the experimental group in the post - test was 20.5 with a standard deviation of 1.51, while the mean score of the control group in the pre- test was 9.5 with a standard deviation of 1.11 and the mean in the post-test was 11 with a standard deviation of 1.31. This detects the mean of the experimental group on the post- test was seemingly different and higher than that of the control group on the posttest. To scrutinize if the means differences between the experimental and control groups were statistically significant, one-way ANCOVA analysis was calculated. The results are presented in table 2 below.

TABLE 2. ANCOVA analysis for the differences in teaching performance scale between the experimental and control groups

\begin{tabular}{ccccccc}
\hline Source & $\begin{array}{c}\text { Type III Sum } \\
\text { of Squares }\end{array}$ & Df & $\begin{array}{c}\text { Mean } \\
\text { Square }\end{array}$ & F & Sig. & $\begin{array}{c}\text { Eta } \\
\text { Squared }\end{array}$ \\
\hline Pre-test & 25.17 & 1 & 25.17 & 18.17 & $* 0.00$ & 0.223 \\
$\begin{array}{c}\text { Group (training } \\
\text { program) }\end{array}$ & 467.91 & 1 & 499.81 & 203.43 & $* 0.00$ & 0.802 \\
\hline
\end{tabular}




\begin{tabular}{cccc}
\hline Error & 748.93 & 36 & 1.66 \\
Total & 1242.01 & 38 & \\
Corrected Total & 673.13 & 37 & \\
& a. Squared $=.756$ (Adjusted & Squared $=.755$ ) \\
\hline * Significant level at $\alpha=0.05$
\end{tabular}

Table 2 unveils that there were statistically significant differences between the experimental and the control groups in the EFL teacher's performance in teaching listening comprehension at $\alpha=0.05$, since $F$ value was 203.43 with statistically significant level 0.00 which is significant at $\alpha=0.05$.

In order to identify the favor of differences between the experimental and control group, adjusted means for both the experimental and control groups in the post test were calculated by SPSSS as appeared in table 3

TABLE 3. The adjusted means and standard deviations for both the experimental and control groups in the post- test

\begin{tabular}{lcccc}
\hline \multirow{2}{*}{ Group } & \multirow{2}{*}{ Mean } & \multirow{2}{*}{ Std. Error } & \multicolumn{2}{c}{ 95\% Confidence Interval } \\
& & & Lower Bound & Upper Bound \\
\hline Experimental & 20.5 & 0.24 & 18.13 & 19.10 \\
Control & 11 & 0.24 & 12.15 & 13.12 \\
\hline
\end{tabular}

As table 3 shows that the adjusted mean of the experimental group in the post-test was 20.5 out of 25 and it is higher than the adjusted means of the control group in the post-test which was 11 out of 25 . Thus, the null hypothesis " there are no statistically significant differences at $\alpha=0.05$ in the mean scores of the performance of EFL teachers in teaching listening comprehension scale between the experimental group and the control group attributed to the training program (Oxford's model of strategy-based instruction and the conventional ones) was rejected. Instead the alternative hypothesis was accepted, which refers to statistically significant differences at $\alpha=0.05$ to the effectiveness of the proposed training program based on Oxford's model of strategy-based instruction on the performance of female EFL teachers in teaching listening comprehension in favor of the experimental group.

Question no 2: do EFL female teachers employ the model's strategies after participating in the training program?

EFL teacher's performance in teaching listening comprehension needs to be supported by different tools. To this end, the researcher employed a non-participant observation technique to investigate the extent to which Oxford's model of strategy-based instruction was implemented by EFL teachers. An observational checklist was developed by the researcher and used to observe 12 EFL teachers from each group after being exposed to the training program (proposed training program based on Oxford's model and conventional one). This was to make sure EFL teachers were able to employ Oxford's model of strategy-based instruction while teaching listening comprehension. Frequencies and percentages were used to identify which of the strategies teachers used most. Table (4) below presents the frequencies and the percentages of those strategies.

TABLE 4. Frequencies and Percentages of EFL teachers' implementation of Oxfords model of strategy based instruction

\begin{tabular}{|c|c|c|c|c|c|}
\hline \multirow[b]{2}{*}{ No } & \multirow[b]{2}{*}{$\begin{array}{l}\text { Oxford's model of strategy based } \\
\text { instruction }\end{array}$} & \multicolumn{2}{|c|}{ Experimental } & \multicolumn{2}{|c|}{ Control } \\
\hline & & Frequencies & Percentages & Frequencies & Percentages \\
\hline \multicolumn{6}{|c|}{ Memory strategies } \\
\hline 1 & Creating mental linkages & 10 & $\% 83.3$ & 5 & $\% 41.6$ \\
\hline 2 & Applying images and sound & 9 & $75 \%$ & 4 & $33.3 \%$ \\
\hline 3 & Reviewing well & 7 & $58.3 \%$ & 5 & $41.6 \%$ \\
\hline 4 & Employing action & 9 & $75 \%$ & 4 & $33.3 \%$ \\
\hline
\end{tabular}




\begin{tabular}{|c|c|c|c|c|c|}
\hline \multicolumn{6}{|c|}{ Cognitive strategies } \\
\hline 5 & Practicing listening & 8 & $66.6 \%$ & 5 & $41.6 \%$ \\
\hline 6 & Receiving and sending messages & 9 & $75 \%$ & 5 & $41.6 \%$ \\
\hline 6 & Analyzing and reasoning & 8 & $66.6 \%$ & 4 & $33.3 \%$ \\
\hline 7 & Creating structure for input and output & 9 & $75 \%$ & 4 & $33.3 \%$ \\
\hline \multicolumn{6}{|c|}{ Compensation strategies } \\
\hline 8 & \multicolumn{4}{|c|}{ Metacognitive strategies } & $33.3 \%$ \\
\hline 9 & Centering students' learning & 9 & $75 \%$ & 2 & $16.6 \%$ \\
\hline 10 & $\begin{array}{l}\text { Guiding students how to arrange and plan } \\
\text { their learning. }\end{array}$ & 9 & $66.6 \%$ & 3 & $25 \%$ \\
\hline 11 & $\begin{array}{l}\text { Helping students how to evaluate their } \\
\text { learning }\end{array}$ & 9 & $75 \%$ & 4 & $33.3 \%$ \\
\hline \multicolumn{6}{|c|}{ Affective strategies } \\
\hline 12 & Lowering students' anxiety & 7 & $58.3 \%$ & 2 & $16.6 \%$ \\
\hline 13 & Encouraging students & 9 & $75 \%$ & 3 & $\% 25$ \\
\hline 14 & Taking students' emotional temperature & 9 & $75 \%$ & 5 & $41.6 \%$ \\
\hline \multicolumn{6}{|c|}{ Social strategies } \\
\hline 15 & Fostering students to ask questions & 7 & $58.3 \%$ & 3 & $\% 25$ \\
\hline 16 & $\begin{array}{l}\text { Encouraging students to cooperate with } \\
\text { each other. }\end{array}$ & 7 & 58.3 & 4 & $\% 33.3$ \\
\hline 17 & $\begin{array}{l}\text { Encouraging students to empathizing with } \\
\text { each other }\end{array}$ & 8 & 66.6 & 4 & $\% 33.3$ \\
\hline
\end{tabular}

The findings presented in table 4 shows that EFL female teachers in the experimental group employed Oxford's model of strategy-based instruction to a significant extent; that is, at least 7 observed EFL teachers employed each of the stated strategies in the checklist.

For example, 10 EFL teachers employed creating mental linkages and it recorded the highest frequencies, whereas reviewing well, lowering student's anxiety, fostering students to ask questions and encouraging students to cooperate with each other showed 7 frequencies, and the total frequencies of using the (17) techniques were (161) times. In the control group, these frequencies ranged between zero and five out of 12 EFL teachers, and the total frequencies of using the (17) techniques were (51) times. The researcher assumed that female EFL teachers in the experimental group employed Oxfords' model of strategy-based instruction according to the instructional situations and they no longer depended on one single strategy thereby their teaching performance was optimized.

\section{DISCUSSION}

Overall, the proposed training program played a pivotal role in improving EFL female teachers' performance in teaching English listening comprehension. The positive effect of the proposed training program was attributed to the general focus of the training on equipping EFL teachers with a repertoire of instructional strategies to help teachers to engage in teaching spoken texts and help students interact and comprehend them. Additionally, Oxford's model of strategybased instruction has been proven by research to be effective in student achievement; according to Gamage (2003), Oxford's model of strategy based instruction is attractive in a number of ways. It is designed in a way to suit not only students learning English as a second/foreign language (ESL/EFL) in America but also students of any country.

The model used as an effective tool for measuring strategy preferences and developmental stages in strategy usage. The model also has a useful underlying structure for strategy categorization and employs a wide range of strategies, all items of which are checked and rechecked for validity and reliability. Thereby, if teachers are aware of these strategies and their positive effect on their students, they become interested in learning how to apply them. 
Furthermore, the proposed training program presented Oxford's model in a framework that helped teachers identify when and how to employ each strategy and its techniques.

Likewise, Oxford's is a comprehensive model of direct strategy instruction which shows an apparent and functional way of how to incorporate strategy based instruction into the EFL curricula and methodology. Furthermore, according to Sarafianou and Gavriilidou (2015), this model is effective due to being flexible, and its parts could be adapted to needs of learners and teachers.

Additionally, this model tried to improve EFL teacher's performance in teaching listening comprehension by building on what they already knew and spotting more light on how to help students comprehend the spoken text using the techniques within the model SBI, like activating prior knowledge, guessing intelligently, analysing what learners listened to, and creating a comprehensible structure for the input and output, teachers need to apply affective strategies like loweing learners' anxiety, encouraging learners to ask questions, and create a copperative learning atmosphere among learners.. In other words, it tends to transform teacher's performance from mediocre to high quality (Miller, 2014).

The researcher believed that teacher's performance was significantly improved; they acquired a variety of techniques to use while teaching, and could smoothly move from one stage of teaching to another. Furthermore, teachers learned to create a suitable and cooperative atmosphere in which students were quite familiar with what they were going to do in terms of content and language. The teachers abandoned their centeredness in the conversation by letting students work in groups using the techniques of classifying spoken ideas into meaning units, and working cooperatively to ask and answer questions.

The findings of this study have been supported by previous reported studies. For example, Zhang (2012), Ramli, Sankah, and Prayogo (2019), Rahimirad and Zare-ee (2015), Sarafianou and Gavriilidou (2015), and Ulum (2015) found that it is essential to train EFL learners on how to use these strategy-based instruction, as they are teachable, flexible and help students to be responsible for their own learning, and development.

Additionally, the findings of the study of Giraldo (2014) aligned similarly with those of the present study. He found that the professional development program had a direct effect on optimizing English language teachers' performance; they demonstrated awareness of the effective strategies they were exposed to in the program. Results also showed that teacher's performance before the training program was traditional, focusing on structure and translation in their teaching. However, after finishing the program, they demonstrated a communicative way of teaching by engaging students in the learning process, identifying the learning objectives and providing feedback, and increasing the motivation of students. Besides, both Giraldos' study and the present study used classroom observation after conducting the training program to identify the improvement in teachers' performance.

However, research has not often focused on the performance and the professional development of teachers. Most research has emphasized the effect of pedagogy on student achievement, finding that it is beneficial and significant. However, researchers ignored the fact that it is necessary to know the quality of teachers to make sure the students learn effectively. The better teachers teach, the more students learn. It is not logical to expect teachers to be qualified, professional, and effective without training them and equipping them with effective methods (Al-husban \& Alkhawaldeh, 2016)

In the context of teaching listening comprehension, training teachers to teach listening comprehension, the neglected skill, needs more attention from researchers and educators. Teaching listening comprehension has traditionally been considered un-teachable; teachers were not trained to use the strategies nor were students asked to practice them. According to Ulum (2015), EFL listening skills had been abandoned because it was thought that listening skills could be learned automatically. Additionally, the current study supports the 
recommendations of many researchers that these strategies could be taught (Oxford, 1990; Oxford, 2011; Ulumi, 2015; Sarafianou and Gavriilidou, 2015; Zhang, 2015). However, EFL learners need scaffolding and training to be able to use them from their teachers; therefore, EFL teachers should be professionally developed and familiar with this model to be able to teach this skill using SBI.

Regarding the second question: observed teachers were comfortable in engaging all students in the learning process by using various techniques according to EFL learners' preferences and needs.

On the other hand, the control group's performance in teaching listening comprehension was lower than that of the experimental group, as displayed in table 4 . This could be due to the current methods employed in teaching listening comprehension, which are characterized by Ulum (2015). The author explains that EFL teachers do not teach students how to lower their anxiety, learn cooperatively, set goals and objectives, take notes, using key words, summarize, and think inductively or deductively. Instead, EFL teachers spend time reading the listening texts from the teachers' guide and asking students questions to assess their understanding without demonstrating any listening comprehension strategy.

That is to say, EFL teachers of the experimental group became cognizant of how, why, and when to use these strategies. For instance, most of the observed teachers guided students to create mental linkages, apply images and sounds, receive and send messages while listening. They guided students to arrange and plan their learning, to work with each other cooperatively and to empathize with each other. Furthermore, EFL teachers recognized that teaching listening comprehension could be done by using cognitive, metacognitive, social and affective strategies.

\section{LIMITATIONS OF THE STUDY}

Although the results of the study are promising, the following issues can be considered as limitations of the generalizations of the findings of the present study:

The study was limited to EFL female teachers at the primary educational stage in Amman, the capital of Jordan. Furthermore, the sample was chosen purposefully from the First Directorate of Education in Amman. The instruments and the training program were developed and adapted by the researcher herself. Hence, the findings of this study have been limited by the instruments' psychometric traits or characteristics (i.e., validity and reliability).

Additionally, this study was limited to the second semester of the academic year 2018/2019 and to female EFL teachers. The study also depended on training EFL teachers using Oxfords' model of strategy-based instruction of listening comprehension to leverage their performance in teaching listening comprehension. Therefore, replication the study in other population samples is necessary to establish validity and reliability.

\section{CONCLUSION}

The study examined the effects of SBI on EFL teachers' performance in teaching listening comprehension. It was revealed that the performance of teachers in the experimental group outperformed those who were trained using the traditional way, and the observation results revealed observed teachers from the experimental group showed more frequencies in employing the strategies and techniques of Oxfords' model.

According to the previous research reported in this study, teachers are the most important factor in improving student learning; therefore, teacher training should be on the top 
agenda of any educational system, and attention should be given to what EFL teachers perform in the classroom.

In the context of the current study, the results generated several implications for decision makers regarding the optimization of potentials of teachers by using effective research findings and bridging the gap between theory and practice. Additionally, the results of this study may be beneficial to the managers of the MoE when manipulating instructional methods to improve student achievement.

This study also highpoints the crucial need to develop the field of training teachers and building their abilities. This can be done by formulating a strategic policy that identifies the needs of teachers, designs training programs based on these needs, and do follow up observations for teachers to identify their performance in the classroom. In this way, the quality of teachers can be enhanced.

Although the current study did not target to measure the effect of the proposed training program on student learning, the research findings proposed that when the quality of instruction optimizes, student learning optimizes as a result (Wagner, 2001). Besides, the researcher does not suggest that SBI of Oxford is a magic solution to instantly improve teacher performance. Indeed, according to Oxford (2001) and Marzano (2011), no instructional strategy works well in all situations; they are just tools and their effectiveness relies on teacher's effectiveness and their willingness to teach effectively, and learners' needs and preferences.

In the light of the findings of the current study, the researcher recommends that conducting further research using the model in other stages and directorates, using a larger number of participants.

\section{REFERENCES}

Abril Molina, H. Y. \& Pardo, A. E. (2016). Teacher Development Program On Teaching Listening Using Virtual Resources At A Public School. Spain: Universidad Libre De Colombia, Spain

Abu-Mwais, H., \& Smadi, O. (2017). The Effect of an Integration-Based Instructional Strategy on Developing EFL Students' Listening Skills at Al-Al Bayt University. Arab World English Journal (AWEJ). Vol. $8(25), 355-371$

Al-Husban, N. \& Alkhawaldeh, A. (2016). Exploring female EFL teachers' knowledge of Marzano's researchbased instructional strategies and its relationship with their level of performance in teaching reading comprehension. Dirasat, Educational Sciences. Vol. 43(5), 2195-2207

Al-Saleem, B. (2010). The status of EFL teacher education in Jordan. Arab World English Journal. Vol. 2(2), 186208.

Alam, Z. (2009). Developing listening skills for tertiary level learners. Dhaka University Journal of Linguistics. Vol. 2(3), 19-52

Alrawashdeh, A. I., \& Al-zayed, N. N. (2017). Difficulties that english teachers encounter while teaching listening comprehension and their attitudes towards them. English Language Teaching, vol. 10(5), 167-178.

Amaluddin, M., Salasiah A., Mardiah, A, (2018) developing teaching model for listening comprehension by using audio visual aids and metacognitive strategy, The Asian ESP Journal. Vol. 14(2),20-32

Bani Abdo, I. \& Breen, G. (2010). Teaching EFL to jordanian students: new strategies for enhancing English acquisition in a district middle eastern student population, Creative Education. Vol. 1(2), 39-50.

Bell, C. L. (2018). Critical listening in the ensemble rehearsal: A Community of learners. Music Educators Journal. Vol. 104(3), 17-25.

Chien, C. N. \& Wei, L. (1998). The strategy use in listening comprehension for EFL learners in Taiwan. RELC Journal. Vol. 29(1), 66-91

Dahlberg, L. (2016). Learning strategies for reading and listening in the Swedish national syllabus for English: $a$ case study of four English language teachers' best practices. Retrieved September 12, 2019 from http://lup.lub.lu.se/student-papers/record/8884877

Darling-Hammond, L. (2009). Recognizing and enhancing teacher effectiveness, International Journal of Educational and Psychological Assessment. Vol. 3(1), 1-24.

Education First English Proficiency Index, (2014). Comparing English Skills between Countries, EFEPI report. Retrieved October 23, 2019 from http://www.ef.com/wwar/epi/ 
Fathi, J. \& Hamidizadeh, R. (2019). The contribution of listening strategy instruction to improving: second language listening comprehension: a case of iranian EFL learners. International Journal of Instruction. Vol. 12(2), 17-32

Field, J. (1998). Skills and strategies: towards a new methodology for listening. ELT Journal. Vol. 52(2),110118 .

Gilakjani, A. P. \& Sabouri, N. B. (2016). The significance of listening comprehension in English language teaching. Theory and Practice in Language Studies. Vol. 6(8), 1670-1677.

Hamouda, A. (2013). An investigation of listening comprehension problems encountered by Saudi students in the EL listening classroom. International Journal of Academic Research in Progressive Education and Development. Vol. 2(2), 113-155.

Hasan, A. (2000) Learners' perceptions of listening comprehension problems. Language, Culture and Curriculum. Vol. 13(2), 137-153.

Hein, G. (1991). Constructivist learning theory. CECA (International Committee of Museum Educators) Conference.Cambridge: Lesley Colleage. Retrieved November 13, 2019 from https://www.exploratorium.edu/education/ifi/constructivist-learning

Khan, M. (2011). Challenges of teaching and learning English and management, Global Journal of Human Social Sciences. Vol. 11(8), 68-80.

Krebt, D. M., \& Al-Rifai, F. K. (2013). The effect of proposed teaching listening strategies programme on Iraqi EFL university students listening comprehension. Al-USTATH. Vol. 206(2), 1-26.

Lear, M. F, (2019), voices of english teachers on professional development, The Asian ESP Journal. Vol. 15(1.2), 198-224

Manzano, B. A. (2018). Examining the Oral Communication Strategies Used by a Group of Nepalese Adult Learners in an ESL Context. 3L: Language, Linguistics, Literature ${ }^{\circledR}$. Vol. 24(1), 84-96

Marzano, R. (2011). 2010-2011 Adams 50 Instructional Model Study [PDF file] (pp. 1-50). Englewood: Marzano Resources. Retrieved November 16, 2019 from https://www.marzanoresources.com/2010-2011-adams50-instructional-model-study

Miller, S. (2014). In-service teacher training and coaching on marzano's instructional strategies: An action research study. Unpublished Ph.D thesis, Capella University, Minneapolis.

Moradi, K. (2013). The impact of listening strategy instruction on academic lecture comprehension: A case of Iranian EFL learners. Procedia-Social and Behavioral Sciences. Vol. 70, 406-416.

Obeidat, N. K., \& Abu-Melhim, A. R. (2008). Common practice in teaching English listening skills at elementary schools in Jordan. International Forum of Teaching and Studies. Vol. 4(2), 33-39

Osada, N. (2004). Listening comprehension research: A brief review of the past thirty years. Dialogue. Vol. 3(1), 53-66

Oxford, R. (1990). Language learning strategies: what should every teacher know. New York: Heinle \&Heinle publishers, 3 .

Oxford, R. L. (Ed.). (2003). Language learning styles and strategies. Mouton de Gruyter

Philip, B., Tan, K. H., \& Jandar, W. (2019). Exploring Teacher Cognition in Malaysian ESL Classrooms. $3 L$ : Language, Linguistics, Literature ${ }^{\circledR}$. Vol. 25(4), 156-178.

Rahimi, A. H. (2012). On the role of strategy use and strategy instruction in listening comprehension. Journal of Language Teaching \& Research. Vol. 3(3), 188-192.

Rahimirad, M. \& Zare-ee, A. (2015). Metacognitive strategy instruction as a means to improve listening selfefficacy among Iranian undergraduate learners of English. International Journal of Instruction. Vol. 8(1), 117-132.

Ramli, M. N., Saukah, A. \& Prayogo, JA (2019). Word recognition from speech, syntactic knowledge, metacognitive awareness, self-efficacy as determination for L2 listening comprehension. International Journal of Instruction. Vol. 12(3), 89-104

Sarafianou, A. \& Gavriilidou, Z. (2015). The Effect of strategy-based instruction on strategy use by uppersecondary greek students of EFL. Electronic Journal of Foreign Language Teaching. Vol. 12(1), 21-34

Sary, F. P. (2017). Teaching critical listening to young learners in indonesian EFL,context. Indonesian EFL Journal. Vol. 1(1), 41-47.

Sulaiman, N. A., Salehuddin, K. \& Khairudin, R. (2020). Reading English Academic Texts: Evidence from ESL Undergraduates' Eye Movement Data. 3L: Language, Linguistics, Literature $®$, 26(1), 60-78

Ulum, O. (2015). Listening: The ignored skill in EFL context. International Journal of Humanities Social Sciences and Education (IJHSSE). Vol. 2(5), 72-80.

Vandergrift, L. (2003). From prediction through reflection: guiding students through the processof L2 listening. The Canadian Modern Langage Review/La reviue canadiennes deslangues vivantes. Vol. 59(3), 129-141

Wagner, T. (2008). The Global achievement gap [PowerPoint slides]. Retrieved November 24, 2019 from https://www.cosa.k12.or.us/downloads/profdev/Seaside\%202009/Tony\%20Wagner.pdf 
Zeng, Y. \& Goh, C. (2018). A self-regulated learning approach to extensive listening and its impact on listening achievement and metacognitive awareness. Studies in Second Language Learning and Teaching. Vol. $8(2), 153-164$.

Zhang, Y. (2012). The impact of listening strategy on listening comprehension. Theory \& Practice in Language Studies. Vol. 2(3), 625-629.

Zobler, A. C. (2010). Effects of listening strategies instruction on listening comprehension, oral proficiency, and metacognition on second language learners (Doctoral dissertation). Retrieved November 29, 2019 from https://repository.wcsu.edu/educationdis/16 